\title{
PEMANFAATAN TEKS DRAMA BUNGA RUMAH MAKAN KARYA UTUY TATANG SONTANI DALAM PEMBELAJARAN BAHASA INDONESIA DI SMA (KAJIAN PSIKOLOGI SASTRA DAN NILAI PENDIDIKAN)
}

\author{
Asprilla Wisnu A, Andayani, Slamet \\ Universitas Sebelas Maret \\ Email: pillawisnu95@gmail.com
}

\begin{abstract}
Abstrak: Salah satu pembelajaran sastra di SMA adalah pembelajaran naskah drama. Konflik batin merupakan permasalahan yang sering dikaji dalam naskah drama. Peneliti memilih mengkaji pembelajaran drama karena naskah drama mengandung nilai-nilai kehidupan. Penelitian ini bertujuan untuk mendeskripsikan dan menjelaskan (1) unsur intrinsik naskah drama Bunga Rumah Makan karya Utuy Tatang Sontani; (2) konflik batin yang dialami tokoh utama naskah drama Bunga Rumah Makan karya Utuy Tatang Sontani; (3) nilai pendidikan dalam naskah drama Bunga Rumah Makan karya Utuy Tatang Sontani; (4) relevansi hasil temuan naskah drama Bunga Rumah Makan karya Utuy Tatang Sontani sebagai bahan ajar Bahasa Indonesia di Sekolah Menengah Atas. Jenis penelitian ini adalah penelitian kualitatif, menggunakan metode analisis isi dengan kajian psikologi sastra. Sumber penelitian ini berupa dokumen naskah drama Bunga Rumah Makan karya Utuy Tatang Sontani, serta informan (guru Bahasa Indonesia Sekolah Menengah Atas) dan penilaian kepibadian B3. Teknik pengumpulan data yang digunakan adalah teknik analisis dokumen, teknik pustaka dan teknik wawancara. Teknik yang digunakan untuk menguji validitas adalah teknik triangulasi sumber data dan triangulasi teori. Hasil penelitian dapat dijabarkan sebagai berikut. Pertama dalam unsur intrinsik yang terkandung dalam naskah drama Bunga Rumah Makan karya Utuy Tatang Sontani terdapat tema, tokoh, latar, alur, dan amanat. Kedua, terdapat konflik batin yaitu kebutuhan fisiologis, kebutuhan rasa aman, kebutuhan rasa cinta dan memiliki, kebutuhan harga diri, kebutuhan aktualisasi tokoh utama yang belum terpenuhi. Ketiga, terdapat nilai pendidikan yaitu nilai religius, pendidikan moral, pendidikan sosial. Keempat, hasil temuan dari naskah drama Bunga Rumah Makan karya Utuy Tatang Sontani ini relevan untuk dijadikan bahan ajar Bahasa Indonesia di Sekolah Menengah Atas khususnya kelas XI mengenai unsur naskah drama. Dengan demikian dapat disimpulkan bahwa dari hasil penelitian struktur drama dan kutipankutipan yang terkandung dalam hasil penelitian naskah drama Bunga Rumah Makan karya Utuy Tatang Sontani dapat dimanfaatkan sebagai bahan ajar.
\end{abstract}

Kata Kunci: psikologi, nilai pendidikan, bahan ajar bahasa Indonesia.

\section{THE UTILIZATION OF DRAMA TEXT BUNGA RUMAH MAKAN BY UTUY TATANG SONTANI IN LITERATURE LEARNING IN SENIOR HIGH SCHOOL (A STUDY OF LITERATURE PSYCHOLOGY AND EDUCATION VALUES)}

Abstract: One of the literary studies in high school is drama script learning. Inner conflict is a
problem that is often studied in drama scripts. Researchers chose to study drama learning because
drama scripts contain life values. This study aims to describe and explain (1) the intrinsic elements

BASASTRA Jurnal Bahasa, Sastra, dan Pengajarannya

Volume 9 Nomor 2, Oktober 2021, P-ISSN 2302-6405, E-ISSN 2714-9765 
of the drama script Bunga Rumah Makan by Utuy Tatang Sontani; (2) the inner conflict experienced by the main character of the drama Bunga Rumah Makan by Utuy Tatang Sontani; (3) the value of education in the drama script Bunga Rumah Makan by Utuy Tatang Sontani; (4) the relevance of the findings of the drama script Bunga Rumah Makan by Utuy Tatang Sontani as an Indonesian language teaching material in high schools. This type of research is qualitative research, using content analysis methods with literature psychology studies. The source of this research is the document of the drama Bunga Rumah Makan by Utuy Tatang Sontani, as well as the informant (Indonesian high school teacher) and B3 personality assessment. Data collection techniques used were document analysis techniques, library techniques and interview techniques. The technique used to test the validity is the data source triangulation technique and theory triangulation. The research results can be described as follows. First, in the intrinsic elements contained in the drama script Bunga Rumah Makan by Utuy Tatang Sontani, there are theme, character, setting, plot, and message. Second, there are inner conflicts, namely physiological needs, security needs, love and belonging needs, self-esteem needs, and actualization needs of the main character that have not been met. Third, there are educational values, namely religious values, moral education, social education. Fourth, the findings from the drama script Bunga Rumah Makan by Utuy Tatang Sontani are relevant to be used as teaching material for Indonesian in high schools, especially class XI regarding the elements of drama scripts. Thus it can be concluded that from the results of the research on the structure of the drama and the quotations contained in the research results of the drama script Bunga Rumah Makan by Utuy Tatang Sontani can be used as teaching materials

Keywords: psychology, educational value, Indonesian language teaching materials.

\section{PENDAHULUAN}

Pertumbuhan dan perkembangan karya sastra di era globalisasi saat ini sangat pesat, pengarang karya sastra terus berlomba-lomba dalam menciptakan karya sastra yang terbaik. Salah satu karya sastra yang terus tumbuh dan berkembang di era globalisasi adalah drama. Drama merupakan karya sastra yang ditulis dalam bentuk dialog dan babak. Hal itu sejalan dengan pendapat Waluyo (2001: 2), yang menyatakan bahwa drama adalah salah satu karya sastra yang ditulis menggunakan bentuk dialog dan berdasarkan konflik batin dan drama dapat untuk dipentaskan. Berbeda dengan karya sastra lainnya dalam menikmati karya sastra drama dapat dinikmati dalam dua pilihan yaitu dinikmati dengan cara membaca naskah drama atau menonton naskah drama yang dipentaskan.

Pengarang dalam menciptakan karya sastra selalu memperhatikan kehidupan masyarakat di lingkungannya karena karya sastra lahir dari imajinasi pengarang yang secara tidak langsung dipengaruhi oleh kehidupan masyarakat. Jadi, hubungan antara karya sastra dan kehidupan masyarakat saling terkait. Hal itu sejalan dengan pendapat Djojosuroto (2006: 58), yang menyatakan bahwa "Dasarnya karya sastra adalah cerminan dan dapat dijadikan sebagai refleksi dari kehidupan masyarakat". Sebagai cerminan tidak sepenuhnya isi dari karya sastra sama persis dengan kehidupan masyarakan. Akan tetapi, ada sudut pandang yang memberikan pelajaran terhadap persoalan-persoalan yang terjadi di lingkungan masyarakat.

BASASTRA Jurnal Bahasa, Sastra, dan Pengajarannya

Volume 9 Nomor 2, Oktober 2021, P-ISSN 2302-6405, E-ISSN 2714-9765 
Pengarang dalam menciptakan karya sastra drama, novel dan karya sastra lainya tentunya harus memperhatikan tentang unsur pembangun karya sastra tersebut, dalam menciptakan karya sastra drama harus memperhatikan struktur fisik (kebahasaan) dan unsur struktur batin (semantik). Hal itu sejalan dengan pendapat Waluyo (2002: 8-30), yang menyatakan bahwa struktur drama meliputi tema, plot, penokohan, tempat, dialog, perwatakan, amanat dan petunjuk teknis. Tanpa adanya struktur pembangun yang berisikan tema, plot, penokohan, tempat, dialog, perwatakan, amanat dan petunjuk teknis maka karya tersebut tidak dapat dinamakan sebagai karya sastra drama. Hasil penelitian Yanti \& Hidayatullah (2018) menyatakan bahwa karya sastra memiliki dua tujuan ganda, yaitu sebagai penghibur masyarakat dan sebagai penyampai amanat dari penulis kepada pembaca. Karya sastra drama menyuguhkan banyak permasalahan yang diangkat dari cerita kehidupan di lingkungan masyarakat, permasalahan dalam kehidupan masyarakat erat dengan pemenuhan kebutuhan yang harus dipenuhi demi melanjutkan hidup. Tingkah laku manusia dapat memengaruhi kehidupan manusia dalam memenuhi kebutuhan hidup manusia yang memuaskan. Tingkah laku dalam memenuhi kebutuhan manusia berkaitan dengan psikologi sastra di mana psikologi sastra merupakan cermin dalam kehidupan yang dapat dilihat dalam kehidupan seseorang dalam memenuhi kebutuhan.

Terdapat beberapa teori yang memuat tentang kebutuhan hidup manusia dari sejumlah ahli psikologi sastra salah satunya adalah teori Abraham Maslow. Hal itu menjadikan para pengarang untuk memunculkan beberapa konflik di setiap tokoh dalam drama, konflik yang sering muncul dalam naskah drama salah satunya adalah mengenai psikologi sastra khususnya konflik batin. Konflik batin merupakan permasalahan yang sering muncul di berbagai naskah drama.

Naskah drama Bunga Rumah Makan karya Utuy Tatang Sontani menyajikan permasalahan konflik batin yang dilahirkan oleh pengarang. Konflik batin merupakan permasalahan yang sering muncul dan konflik batin sendiri terjadi karena adanya ketidakseimbangan antara apa yang dipikirkan dan apa yang dilakukan sehingga menimbulkan konflik dan memengaruhi tingkah laku. Hal itu sejalan dengan pendapat Sujanto, dkk., (2006: 12) yang menyatakan bahwa konflik batin adalah perbuatan yang dilakukan dan bertentangan dengan suara batin, dan dilakukan dalam kehidupan yang sadar, di mana pertentangan tersebut akan menjadi penyebab pecahnya pribadi seseorang, sehingga dalam jiwa seseorang akan merasakan konflik-konflik jiwa. Dalam menganalisis konflik batin, peneliti menggunakan pendekatan psikologi sastra, karena psikologi sastra mampu memberikan gambaran tentang sastra 
dan tentang aspek kejiwaan pengarang yang ditampilkan dalam tokoh drama. Peneliti dalam menganalisis konflik batin menggunakan pendekatan psikologi dan mengacu pada teori Abraham Maslow tentang kebutuhan manusia. Psikologi sastra merupakan salah satu jenis kajian sastra dan psikologi memiliki sifat interdisipliner, dikatakan sebagai interdisipliner karena psikologi sastra mengkaji sastra menggunakan semua konsep dan kerangka teori dalam ilmu psikologi (Wiyatmi, 2011: 23).

Penelitian ini mengintegrasikan antara kajian psikologi sastra, nilai pendidikan, serta direlevansikan sebagai bahan ajar bahasa Indonesia di Sekolah Menengah Atas khususnya kelas XI. Sejauh ini, pembelajaran sastra di Sekolah Menengah Atas cenderung kurang diminati oleh peserta didik. Peserta didik juga belum diarahkan untuk terlibat lebih jauh dalam menganalisis struktur dan menghayati nilai-nilai yang terkandung dalam karya sastra. Pembelajaran sastra hendaknya diarahkan untuk fokus kepada pemerolehan pengalaman secara langsung yang diperoleh peserta didik saat berinteraksi dengan karya sastra. Pengalaman langsung didapatkan dengan membaca dan menulis karya sastra. Kecenderungan pembelajaran sastra yang selama ini terjadi dengan memberikan fakta-fakta, konsep-konsep dan pengertian, justru menjauhkan hakikat pembelajaran sastra itu sendiri (Suhariyadi, 2016: 7071).
Salah satu pembelajaran sastra di SMA adalah pembelajaran naskah drama. Peneliti memilih mengkaji pembelajaran drama karena naskah drama mengandung nilai-nilai kehidupan. Pembelajaran drama membutuhkan naskah drama sebagai bahan ajar yang menarik dan menggugah minat peserta didik sehingga naskah drama yang dipelajari tidak hanya sebatas bacaan tetapi juga memberikan pemahaman terhadap nilai-nilai yang terkandung di dalamnya. Dalam konteks mengapresiasinya, karya sastra harus didekati dan dijiwai terlebih dahulu dengan cara, konkretnya, dibaca dan dipahami dengan sebaik-baiknya (Nuriadi, dkk., 2021: 167). Selain itu, penggunaan drama dalam situasi pendidikan memainkan peran konstruktif dalam pembelajaran proses melalui peningkatan keterampilan siswa (Zaghloul, 2018: 76).

Naskah drama Bunga Rumah Makan merupakan karya dari sastrawan terkemuka angkatan 50 yang bernama Utuy Tatang Sontani, Utuy dilahikan di Cianjur, 31 Mei 1920, meninggal di Moscow, 17 September 1979. Utuy Tatang Sontani merintis karier sejak zaman penjajahan Jepang dan berhasil menulis beberapa karya sastra yang terkenal hingga saat ini. Salah satu karya sastranya yang terkenal adalah naskah drama Bunga Rumah Makan (1945) dalam naskah tersebut berkisah tentang perjuangan seorang perempuan yang bekerja sebagai pelayan di sebuah rumah

BASASTRA Jurnal Bahasa, Sastra, dan Pengajarannya

Volume 9 Nomor 2, Oktober 2021, P-ISSN 2302-6405, E-ISSN 2714-9765 
makan, perempuan tersebut mengalami konflik-konflik hampir setiap hari di rumah makan tersebut. Berdasarkan uraian tersebut diharapkan mampu mendapatkan perhatian ilmiah, oleh karena itu peneliti tertarik untuk meneliti naskah tersebut dengan judul Pemanfaatan Teks Drama Bunga Rumah Makan Karya Utuy Tatang Sontani dalam Pembelajaran Bahasa Indonesia di SMA (Kajian Psikologi Sastra dan Nilai Pendidikan).

\section{METODE}

Penelitian ini bersifat kesusastraan yang tidak terikat oleh waktu. Penelitian ini direncanakan selesai dalam enam bulan dari Oktober 2019-Maret 2020. Pendekatan penelitian ini menggunakan pendekatan kualitatif. Moleong (2012: 5) menyatakan bahwa penelitian kualitatif merupakan penelitian yang mempunyai tujuan untuk memahami tentang apa yang dialami dalam subjek penelitian.

Penelitian kualitatif menghasilkan data deskriptif berbentuk kata-kata, frasa, klausa, kalimat dan paragraf. Dalam hal ini naskah drama Bunga Rumah Makan karya Utuy Tatang Sontani dianalisis dari aspek psikologi sastra dengan mengacu pada pandangan Abraham Maslow, menelaah unsur-unsur drama, konflik batin, nilai pendidikan dan relevansinya sebagai bahan ajar. Metode analisis digunakan untuk menelaah dokumen dan dalam penelitian ini dokumen yang digunakan adalah metode conten analiysis (analisis isi). Metode analisis digunakan untuk menelaah dokumen dan dalam penelitian ini dokumen yang digunakan adalah naskah drama Bunga Rumah Makan karya Utuy Tatang Sontani.

Data dari penelitian ini adalah hasil analisis dari naskah drama Bunga Rumah Makan karya Utuy Tatang Sontani yang sudah sesuai dengan rumusan masalah dalam penelitian ini. Sumber data adalah dokumen dan informan. Sumber data primer adalah naskah drama Bunga Rumah Makan karya Utuy Tatang Sontani yang terdiri dari 48 halaman dan berisikan 21 adegan atau babak. Dan sumber data pendukung lainnya adalah ahli sastra, guru bahasa Indonesia. Teknik sampling dalam penelitian ini menggunakan purposive sampling, yaitu teknik pengambilan sampel yang disesuaikan dengan tujuan penelitian. Penelitian ini memilah dan memilih berbagai pernyataan yang ada dalam sumber data yang sesuai untuk menjawab rumusan masalah.

Penelitian ini menggunakan teknik triangulasi sumber data dan triangulasi teori. Teknik triangulasi sumber data adalah teknik yang bertujuan untuk mengumpulkan hasil wawancara, trianggulasi sumber data dilakukan peneliti untuk mengumpulkan data melalui proses wawancara dengan guru bahasa Indonesia. Sedangkan teknik triangulasi teori diperoleh dari teori- 
teori yang bersangkutan dengan objek dan permasalahan penelitian.

Teknik pengumpulan data yang digunakan peneliti ini adalah teknik analisis dokumen, teknik pustaka, dan teknik wawancara. Teknik analisis data yang digunakan, yaitu teknik analisis mengalir (flow Analysis Models) dan teknik analisis deskriptif kualitatif. Teknik analisis mengalir digunakan untuk mengumpulkan data unsur intrinsik, konflik batin, dan nilai pendidikan dalam naskah drama. Teknik analisis mengalir dilakukan saling mengalir dengan proses pengumpulan data dilakukan secara bersamaan, teknik mengalir antara lain: periode pengumpulan data, reduksi data, penyajian data, penarikan simpulan/ verifikasi.

Teknik analisis data deskriptif kualitatif digunakan untuk mengumpulkan data mengenai konflik batin dan nilai pendidikan yang terkandung dalam naskah drama. Teknik analisis data deskriptif kualitatif antara lain: tahap pertama, data yang sudah ditemukan dideskripsikan. Tahap kedua, setelah data sudah dideskripsikan data dikategorisasikan sesuai dengan hasil analisis temuan, seperti unsur intrinsik, konflik batin dan nilai pendidikan. Tahap ketiga, setelah data dikategorisasikan kemudian data dikelompokkan menjadi bentuk tabel. Tahap akhir, tahap akhir adalah memberikan simpulan dari semua data yang ditemukan.

\section{HASIL DAN PEMBAHASAN}

\section{Struktur Naskah Drama Bunga Rumah Makan karya Utuy Tatang Sontani}

Drama sebagai karya sastra fiksi memiliki unsur-unsur pembangun yang meliputi tema, tokoh dan penokohan, alur atau plot, latar, dan amanat. Berikut struktur yang dianalisis dalam naskah drama Bunga Rumah Makan karya Utuy Tatang Sontani.

\section{Tema}

Tema merupakan ide pokok utama yang terkandung dalam sebuah naskah drama. Tema mayor merupakan tema yang menjadi gagasan utama karena tema merupakan tema yang menguasai jalannya cerita. Tema mayor dalam Bunga Rumah Makan adalah menampilkan tokoh Iskandar di mana penampilanya sebagai gelandangan yang dipandang buruk oleh sebagian orang, padahal Iskandar orangnya baik. Hal itu dikatakan sebagai tema mayor karena dalam naskah drama tersebut pusat pikiran ceritanya terpusat pada Iskandar yang dipandang buruk oleh beberapa tokoh lain padahal nilai kemanusiaan tidak cukup hanya dinilai dari penampilan seseorang saja.

"Ani : Memangnya aku masih tetap seperti kau ? tidak tahu adat kesopanan, duduk bukan di tempatnya duduk

Iskandar : Aku masih rakyat bebas!

BASASTRA Jurnal Bahasa, Sastra, dan Pengajarannya

Volume 9 Nomor 2, Oktober 2021, P-ISSN 2302-6405, E-ISSN 2714-9765 
Ani : Tapi di sini rumah makan, bukan kebun tempat gelandangan berbuat semuanya Iskandar : Gelandangan? Hmm, ya. Aku menggelandang. Tapi bagiku, lebih baik aku jadi gelandangan daripada seperti kau, diam disini untuk jadi boneka yang mendagangkan kecantikan. (Adegan 13, Hlm. 16)

Tema minor merupakan tema pelengkap karena kehadiran tema minor mempunyai fungsi untuk melengkapi tema minor. Tema minor dalam naskah drama Bunga Rumah Makan digambarkan oleh beberapa tokoh yang ada dalam drama yang memiliki pandangan hidup yang berbeda-beda. Hal itu digambarkan oleh tokoh Iskandar yang memandang bahwa manusia harus hidup apa adanya.

Iskandar: Gelandangan? Hmm, ya. Aku menggelandang. Tapi bagiku, lebih baik aku jadi gelandangan daripada seperti kau, diam disini untuk jadi boneka yang mendagangkan kecantikan. (Adegan 13, Hlm. 16)"

\section{Tokoh dan Penokohan}

Watak Ani

"Ani: Saya membantu pekerjaan koki mas (Adegan 2, HIm. 2)"

Berdasarkan kutipan dialog di atas dapat disimpulkan bahwa Ani memiliki sifat penolong, ditandai dari sikap Ani yang sering membantu pekerjaan koki.

\section{Watak Perempuan}

"Perempuan : saya

hendak membeli

manisan belimbing,

masih ada?

Ani : O, ada nyonya, berapa puluh?

Perempuan : Dua

puluh saja. Lebih dari

dua puluh uangnya

tidak cukup."

\section{(Adegan 3, Hlm. 4)}

Berdasarkan kutipan dialog di atas dapat disimpulkan bahwa tokoh perempuan memiliki watak yang baik hati, karena ia selalu membeli dagangan yang dijual oleh Ani, dan menjadi langganan di rumah makan Sambara.

\section{Watak Pengemis}

"Pengemis : Ampun, nona, ampun

Ani : Ya. Kalau sudah ketahuan, mintak ampun

Pengemis : Saya tidak akan mencuri, kalau saya punya uang.

Ani : Bohong! (Adegan 4, HIm. 5)"

Berdasarkan kutipan dialog di atas dapat disimpulkan bahwa tokoh pengemis berwatak pencuri, meski sering diberi uang oleh Ani, tokoh pengemis masih berani mencuri makanan di rumah makan Sambara.

\section{Watak Sudarma}

"Sudarma : Tak perlu, pemalas biar mati kelaparan. Toh di datang ke sini hanya mengotori tempat ini saja." (Adegan 5, Hlm. 6) 
Berdasarkan kutipan dialog di
atas dapat disimpulkan bahwa Sudarma berwatak pemarah dan pelit, karena ia telah berkata kasar kepada Pengemis dan tidak memberi uang kepada pengemis.

\section{Watak Dua Pemuda}

"Pemuda I : Tapi anehnya saya ini tidak suka dengan yang enak

Ani : Mengapa?

Pemuda II : Sebab dia bukan manusia biasa, Nona. Kkkkkeluarbiasaanya ialah kalau nona sudah sekali kenal dengan diaa, maka dia.....

Pemuda II : Ya, nanti saya kan menelpon kesini, asal saja diberi tahu nama nona dan nomor telpon disini. (Adegan 9, Hlm. 10)"

Berdasarkan kutipan dialog di atas dapat disimpulkan bahwa dua pemuda tersebut memiliki watak genit, ditandai dari perkataannya yang sering menggoda Ani.

\section{Watak Rukoyah}

"Rukoyah: Aku ingin bertanya, apa keinginan menyerahkan jiwa dan raga kepada laki-laki itu menurut perasaan saja atau juga menurut pikiran? Sebab menurut pendapatku cinta itu baru benar, jika pikirn turut menghitungnya. Tapi ini hanya pendapatku saja, An. Pendapat seseorang perempuan yang tidak mau di pandang lebih rendah oleh laki-laki, oleh makhluk yang umumnya memandang hidup dengan

pikiran. Kalau akan menghadapi laki-laki dengan wawasan saja, alamat akan celakalah aku sebagai perempuan. (Adegan 12, Hlm. 14)"

Berdasarkan kutipan dialog di atas dapat disimpulkan bahwa Rukoyah mempunyai sifat bijaksana. Hal itu dibuktikan dari beberapa perkataannya yang sering menasihati Ani tentang apa itu cinta.

\section{Watak Iskandar}

"Iskandar: (duduk di atas meja). Memang aku duduk di sini tidak untuk belanja, tapi untuk... menengok, melihat kau. (Adegan 13, Hlm. 15)"

Berdasarkan kutipan dialog di atas dapat disimpulkan bahwa Iskandar memiliki watak genit, ditandai dengan gaya bicaranya yang menggoda Ani.

\section{Watak Karnaen}

"Karnaen : Dari itu, kalau saudara berurusan dengan dia, berarti saudara berurusan pula dengan saya, sebab saya pelindung dia. (Adegan 14, HIm. 17)"

Berdasarkan kutipan dialog di atas dapat disimpulkan bahwa Karnaen berwatak pemberani, ditandai dengan keberaniannya melawan Iskandar demi membela Ani.

\section{Watak Polisi}

"Polisi : Kalau benar ini seperti saya lukisan tadi, pasti saya dapat melacaknya. Kami dari polisi sudah tau di mana dia

BASASTRA Jurnal Bahasa, Sastra, dan Pengajarannya

Volume 9 Nomor 2, Oktober 2021, P-ISSN 2302-6405, E-ISSN 2714-9765 
sering ada. (Adegan 17, Hlm. 21)"

Berdasakan kutipan dialog di atas dapat disimpulkan bahwa tokoh Polisi dalam naskah drama bunga rumah makan memiliki watak yang bertanggung jawab, ditandai dari dialog tersebut yang mana polisi segara mungkin mencari dalang dari pembuat keributan di rumah makan itu.

\section{Watak Usman}

"Usman : (Menghampiri Ani). Sabar, sabar, sabar, nak. Orang sabar itu disayangi Tuhan. (Adegan 17, Hlm. 23)"

Berdasarkan kutipan dialog di atas dapat disimpulkan bahwa Usman berwatak religius, ditandai dengan gaya bicaranya yang selalu mengatasnamakan Tuhan.

\section{Watak Suherman}

"Suherman : Habis sangka saudara, saya mencintai wanita itu untuk kawin? (Adegan 18, HIm. 25)"

Berdasarkan kutipan dialog di atas dapat disimpulkan bahwa Suherman watak pendusta.

\section{Latar atau Setting}

Setting atau latar merupakan suasana, tempat dan waktu terjadinya sebuah alur dalam naskah naskah drama. Pembagian setting atau latar dapat dibagi dalam tiga dimensi, antara lain dimensi tempat, waktu dan ruang (Waluyo, 2002: 23).

\section{Latar Waktu}

"Karnaen : Ah, di pagi hari begini tak ada yang aneh. (melangkah mendekati ani).
Dan dari pada mendengar radio, aku lebih suka mendengar kau bercerita. Kau lebih senang jadi pelayan dari pada mengurus rumah tangga, An?" (Adegan 2, Hlm. 3).

Berdasarkan kutipan dialog di atas dapat disimpulkan bahwa kegiatan yang dilakukan Ani terjadi saat pagi hari di rumah makan Sambara.

\section{Latar Tempat}

"Karnaen: (Memandang ani, kemudia segan menuju тејa tulis, mengangkat telepon).Ya, disini rumah makan sambara, tuan sudarma belum datang saya anaknya. Ya (telepon diletakkan, terus termenung)." (Adegan 3, Hlm. 4)

Berdasarkan kutipan dialog di atas dapat disimpulkan bahwa tempat kejadian tersebut berada di rumah makan Sambara milik Sudarma.

\section{Latar Suasana}

"Karnaen: Tapi aku suka melihat kau masak, An. Karena dengan begitu, kau akan jelas terlihat sebagai wanita yang akan jadi ratu rumah tangga.

Ani: (Pergi mengambil lap di atas gantungan). Ah, mas kalau saya mendengar perkataan " rumah tangga " saya suka gemetar.saya masih suka bekerja seperti sekarang ini. (mengelap radio)." (Adegan 2, HIm. 2-3)

Berdasarkan kutipan dialog di atas dapat disimpulkan bahwa latar suasana yang terjadi adalah latar

BASASTRA Jurnal Bahasa, Sastra, dan Pengajarannya

Volume 9 Nomor 2, Oktober 2021, P-ISSN 2302-6405, E-ISSN 2714-9765 
suasana mesra. Hal itu dibuktikan dengan perkataan Karnaen yang mencoba menggoda Ani.

\section{Alur atau Plot}

Waluyo (2002: 8) menyatakan bahwa plot merupakan jalinan cerita atau kerangka awal hingga akhir yang berada dalam naskah yang merupakan jalinan konflik antara dua tokoh yang berlawanan. Naskah drama Bunga Rumah Makan karya Utuy Tatang Sontani menggunakan plot maju/ agresif hal itu ditandai dengan adanya tahap awal, tahap pertengahan dan tahap klimaks di mana hal itu sejalan dengan pendapat Nurgiyantoro (2012: 154) yang menyatakan bahwa plot maju atau yang sering plot agresif merupakan plot yang menceritakan kronologis, peristiwa yang kemudian menjadi penyebab terjadinya peristiwa tersebut terjadi.

Alur bagian pengenalan merupakan alur yang menceritakan awal mula Ani tiba di rumah makan Sambara. Alur tahap awal yaitu bagian permasalahan konflik awal tokoh utama. Hal tersebut ditandai dengan datangnya Iskandar ke rumah makan tersebut, tetapi ia sama sekali tidak memesan makanan dan hanya mampir duduk saja. alur tahap pertengahan bagian permasalahan lanjutan tokoh utama, di mana pada adegan tersebut Ani kembali bertemu dengan Iskandar dan terjadilah keributan antara Ani dan Iskandar. Alur tahap antiklimaks dibuktikkan masih adanya konflik tetapi tidak sepanas konflik yang terjadi pada adegan sebelumnya. Alur tahap klimaks terjadi saat konflik permasalahan yang sudah mencapai puncak. Alur tahap akhir ditandai dengan meredanya konflik pada drama tersebut dan diakhiri dengan Ani yang memilih pergi bersama Iskandar.

\section{Amanat}

Adapun amanat atau pesan yang hendak disampaikan dalam naskah drama Bunga Rumah Makan karya Utuy Tatang Sontani bahwa setiap manusia di dunia ini mencari penghidupan dengan jalannya sendiri. Masalah baik atau tidak baiknya sikap yang disampaikan bergantung pada watak atau tabiat orang tersebut. Hal ini tidak jauh berbeda dengan keseharian kita dalam kehidupan setiap manusia berbeda watak dan cara memandang orang lain. Sebagai manusia tidak boleh adanya jurang antara si kaya dan si miskin walaupun seseorang disibukkan dengan pekerjaan, hendaklah memberikan perhatian baik kepada orang yang tidak mampu karena sebagian harta kita adalah hak bagi orang lain. Sedangkan si miskin tidak hanya menadahkan tangannya saja, tetapi tetap berusaha dan bekerja demi kelangsungan hidupnya.

\section{Konflik Batin Tokoh Utama Dalam Naskah Drama Bunga Rumah Makan}

Konflik batin tokoh utama naskah drama Bunga Rumah Makan karya Utuy Tatang Sontani dikaji menggunakan teori kebutuhan 
bertingkat milik Abraham Maslow. Teori milik Abraham Maslow disusun sebagai berikut, (a) kebutuhan fisiologis; (b) kebutuhan rasa aman; (c) kebutuhan cinta dan memiliki; (d) kebutuhan harga diri; (e) kebutuhan aktualisasi diri.

\section{Kebutuhan Fisiologis}

Maslow (dalam Mingderop, 2011: 48-49) menyatakan bahwa "kebutuhan fisiologis merupakan kebutuhan dasar manusia dan kebutuhan fisiologis merupakan kebutuhan yng berkaitan dengan berlangsungnya kehidupan manusia. Kebutuhan fisiologis manusia mencakup kebutuhan makan, minum, pakaian, tempat tinggal, seks dan istirahat".

Ani: Saya ini sendirian di dunia ini, tak punya ibu tak punya bapak, dan orang yang saya anggap tempat menumpang diri ternyata tidak sayang (Mengisak)."(Adegan 17, HIm. 23)

Berdasarkan kutipan dialog di atas dapat disimpulkan bahwa tokoh utama Ani tidak mempunyai tempat tinggal tetap. Selama ini ia hanya menumpang hidup di rumah makan milik Sudarma. Semasa ia tinggal di sana, Ani tidak pernah merasakan kasih sayang, sebaliknya ia malah banyak dimanfaatkan orang-orang karena sifat lugu Ani.

\section{Kebutuhan Rasa Aman}

Maslow (dalam Mingderop, 2011: 48-49) menyatakan bahwa "kebutuhan rasa aman akan muncul jika kebutuhan psikologis terpenuhi, kebutuhan rasa aman adalah kebutuhan yang menuntun untuk kepuasan diantaranya adalah rasa aman fisik, stabilitas, ketergantungan, perlindungan dan kebebasan dari dayadaya yang mengancam (penyakit, takut, cemas, bahasa, kerusuhan dan bencana alam)".

"Ani : (Merenung)

Iskandar : (Masuk, berdiri memandang

Ani)

Ani : (Terkejut tegak memandang Iskandar). $\mathrm{O}$ .......engkau! buat apa pula selalu datang ke sini kalau bukan untuk belanja?

Iskandar : (Duduk di atas meja). Memang aku di sini bukan untuk belanja, tetapi untuk...............menengok

melihat kau

Ani : Untuk mengganggu aku!

Iskandar : (Tersenyum pahit). Terima kasih!'(Adegan 13, HIm. 15)

Berdasarkan kutipan dialog di atas dapat disimpulkan bahwa Ani merasakan ketidaknyamanan karena kedatangan Iskandar. Hal itu membuktikan bahwa kebutuhan rasa aman Ani tidak terpenuhi.

\section{Kebutuhan Cinta dan Memiliki}

Maslow (dalam Mingderop, 2011: 48-49) menyatakan bahwa "Kebutuhan rasa cinta dan memiliki meliputi, dorongan untuk bersahabat, keinginan memiliki pasangan, keturunan dan seperti kebutuhan untuk memberi dan menerima cinta".

"Suherman: Habis...? sangka saudara, saya mencintai perempuan itu untuk kawin? 
Usman : Maksud kami tidak begitu, tetapi....

Ani : Sudah! Sudah! Saya tahu, bahwa orang hanya suka pada senyumku, tidak suka kepada air mataku. (Menangis dan pergi ke belakang).

Suherman : Betul-betul sial kedatangan saya hari ini (Melangkah)." (Adegan 18, HIm. 25)

Berdasarkan kutipan dialog di atas dapat disimpulkan bahwa Ani tidak merasakan rasa memiliki dan cinta yang sesungguhnya, karena Suherman yang selama ini telah dianggap menjadi miliknya dan mencintainya justru Suherman bermain-main dengan perasaan Ani. Hal itu membuat kebutuhan rasa memiliki dan dicintai tidak terpenuhi.

\section{Kebutuhan Harga Diri}

Maslow (dalam Mingderop, 2011: 48-49) menyatakan bahwa " jika kebutuhan harga diri manusia ada dua yaitu kebutuhan lebih rendah dan lebih tinggi. Kebutuhan lebih rendah adalah kebutuhan untuk menghormati orang lain, kebutuhan status, ketenaran, kemuliaan, pengakuan, perhatian, reputasi, apresiasi, martabat, bahkan kebutuhan penghargaan orang lain. Sedangkan kebutuhan lebih tinggi adalah kebutuhan penghormatan dari diri sendiri yang meliputi perasaan, keyakinan, kompetensi, prestasi, penguasaan, kemandirian dan kebebasan".

"Usman: Mulai dari rumahnya kami berjalan bersama-sama. Tapi di tengah jalan dia meninggalkan. Katanya mau menunggu aku di sini. Begitulah mertuamu, Ani!
Ani : (Berdiri) mertua saya?

Usman : Akan jadi mertuamu maksudku!

Ani : Tapi paman dari mana datangnya anggapan itu?

Usman : Tidak dari manamana, hanya menurut kepantasan saja dan kebiasaan dalam pergaulan hidup. Menurut kepantasan, siapa berani mengatakan tidak pantas kau jadi istri Karnaen. Menurut kebiasaan, kau dan Karnaen itu sudah bergaul rapat sekali, bukan?

Ani : (Menutup siaran radio) tapi paman....

Usman : Ah, pendapat orang tua tidak usah kau bantah. Tapi betul tadi tuan Sudarman menyuruh aku menyusul?

Ani : Ya. Betul

Usman : Biar ku susul ke sana. (Berjalan keluar)." (Adegan 6, HIm. 7-8)

Berdasarkan kutipan dialog di atas dapat disimpulkan bahwa Ani seperti tidak mempunyai harga diri dan tidak diberikan penghargaan oleh Usman karena Usman menganggap bahwa Ani akan bersedia dan mau untuk disuruh-suruh menjadi istri dari Karnaen dan ketika Ani ingin membantah Usman tidak memperbolehkanya dan Usman tidak memberikan penghargaan kepada Ani dan seolah-olah Ani tidak mempunyai harga diri. Hal itulah yang menyebabkan kebutuhan rasa penghargaan (kebutuhan harga diri) Ani tidak terpenuhi.

\section{Kebutuhan Aktualisasi Diri}

Kebutuhan tingkat akhir menurut Maslow (dalam Mingderop,

BASASTRA Jurnal Bahasa, Sastra, dan Pengajarannya

Volume 9 Nomor 2, Oktober 2021, P-ISSN 2302-6405, E-ISSN 2714-9765 
2011: 48-49) adalah "kebutuhan akan aktualisasi diri. Kebutuhan aktualisasi diri merupakan kebutuhan yang mendorong untuk mengembangkan potensi dan bakat yang berada dalam setiap diri individu". Potensi dan bakat dikembangkan guna untuk memahami perkembangan kepribadian secara menyeluruh agar seseorang mampu mencapai kesenangan, kesejahteraan dengan memanfaatkan potensi-potensi yang ada dalam diri setiap individu

"Ani: Tidak, saya sudah bulat ingin pergi. Saya mau hidup merdeka

Sudarma: Ah..., merdeka bagaimana? Nanti kau sukar mencari pekerjaan, mencari kesenangan seperti di sini

Ani : Saya tidak senang di sini, karena itu saya mau pergi. Saya harus jauhi segala kepalsuan dalam rumah makan ini. Dan akan pergi bersama orang jujur." (Adegan 20, Hlm. 30)

Berdasarkan kutipan dialog di atas dapat disimpulkan bahwa kebutuhan perkembangan kepribadian Ani tidak terpenuhi karena Ani tidak memperoleh kepuasan dan kesejahteraan diri. Oleh karena itu, Ani memberikan diri untuk keluar dari rumah makan tersebut guna untuk mengembangkan potensi dalam diri Ani.

\section{Nilai Pendidikan dalam Naskah Drama Bunga Rumah Makan Karya Utuy Tatang Sontani}

Naskah drama Bunga Rumah Makan karya Utuy Tatang Sontani terdapat nilai pendidikan, penelitian nilai pendidikan penting dilakukan karena hal ini dapat menjadi tolok ukur apakah naskah ini layak dijadikan bahan ajar atau tidak. Berdasarkan hasil penelitian tentang nilai pendidikan yang terdapat dalam naskah drama Bunga Rumah Makan karya Utuy Tatang Sontani ditemukan tiga nilai pendidikan, nilai pendidikan dapat dilihat pada paragraf di bawah ini.

\section{Nilai Pendidikan Religius}

Nilai pendidikan Religius merupakan nilai pendidikan yang wajib dimiliki oleh seorang muslim karena melalui nilai pendidikan religius seseorang tidak akan tersesat dijalan kehidupanya, nilai pendidikan religius dapat dilihat ketika Ani tak mempunyai apa-apa dan merasa menyerah dengan kehidupan ini dan datanglah Usman yang datang menguatkan Ani, seketika itu Ani kembali kuat untuk menghadapi masalah yang ada dikehidupan Ani. Naskah drama Bunga Rumah Makan karya Utuy Tatang Sontani terdapat nilai pendidikan religius.

Ani : Saya ini sendirian di dunia, tak punya ibu tak punya bapak, dan orang yang saya anggap tempat menumpang diri ternyata tidak sayang. (Mengisak)

Usman : (Menghampiri Ani) sabar, sabar, nak. Orang sabar itu disayangi Tuhan". (Adegan 17, Hlm. 23)

Pada cuplikan dialog di atas, bahwa setiap orang yang kesepian dan menyendiri, mereka tidak benar pernah merasa kesepian jika mereka punya Tuhan, karena tuhanlah yang selalu ada Yang Maha Pengasih dan Maha Penyayang. Selain itu, tokoh Usman juga menasihati Ani, bahwa orang sabar itu akan disayang oleh Tuhannya.

Nilai Pendidikan Moral

Nilai pendidikan moral merupakan nilai pendidikan yang harus

BASASTRA Jurnal Bahasa, Sastra, dan Pengajarannya

Volume 9 Nomor 2, Oktober 2021, P-ISSN 2302-6405, E-ISSN 2714-9765 
dimiliki oleh setiap siswa karena melalui pendidikan moral siswa dapat membedakan mana perbuatan yang boleh dilakukan dan mana perbuatan yang tidak boleh dilakukan. Nilai pendidikan moral dalam naskah drama Bunga Rumah Makan karya Utuy Tatang Sontani dapat dilihat ketika Ani mampu bertindak tegas dan memilih perbuatan yang baik dengan pergi dari rumah makan Sambara karena jika Ani terus menjadi pelayan akan banyak masalah yang timbul.

"Polisi : Jadi perkataan nona tadi ,..... Bahwa dia menghina nona itu, tidak benar

Ani : Ya

Polisi : Tidak benar dia sudah melahirkan ejekan, menyebut penipu dan sebagainya kepada nona?

Ani : Betul dia berkata begitu. Tapi saya yang dungu, tidak mau berterus terang, bahwa sebenarnya apa yang dikatakanya itu mengandung kebenaran, bahwa sebenarnya saya sudah dusta kepada diri sendiri dan kepada orang lain".

(Adegan 19, Hlm. 29)

"Ani : (Keluar sambil menjijing koper)

Usman : Mau ke mana, An.

Ani : Saya mau keluar dari sini

Sudarma : Nanti dulu! Nanti dulu! Jangan tergesa-gesa begitu, An! Siapa yang menyuruhmu keluar dari sini? $\mathrm{Aku}$ sayang kepadamu dan berjanji akan menaikkan gajimu, asal jangan pergi dari sini

Ani : Tidak, saya sudah bulat ingin pergi. Saya mau hidup merdeka
Sudarma: Ah......, merdeka bagaimana? Nanti kau sukar mencari pekerjaan, mencari kesenangan seperti di sini

Ani: Saya tidak senang di sini, karena itu saya mau pergi. Saya harus jauhi segala kepalsuan dalam rumah makan ini. Dan akan pergi bersama orang jujur". (Adegan 20, HIm. 30)

Berdasarkan kutipan dialog di atas dapat disimpulkan bahwa Ani memiliki moral yang baik karena Ani dapat dengan tegas milih pilihnnya untuk pergi dari rumah makan tersebut agar Ani dapat terhindar dari hal buruk.

\section{Nilai Pendidikan Sosial}

Nilai pendidikan sosial merupakan nilai yang mengajarkan kepada siswa tentang pentingnya hidup bersosial yang baik dan tidak melulu mementingkan kehidupan individu melainkan mementingkan hidup secara berkelompok. Nilai pendidikan kelompok dalam naskah drama Bunga Rumah Makan karya Utuy Tatang Sontani dapat dilihat ketika tokoh suherman lebih mementingkan kepentingan kelompok daripada kepentingan individu.

"Ani : Saya percaya

Suherman : Tapi janji tentara mesti selalu berdisiplin. Sekarang dinda aku tak akan lama diam disini. (Minum menghabiskan susu)

Ani : Nanti akan datang lagi ke sini?

Suherman : (Memberikan uang) tentu.

Ani : Jam berapa?

Suherman : Tak akan sampai menjelang satu jam. Asal kewajiban sekarang selesai

BASASTRA Jurnal Bahasa, Sastra, dan Pengajarannya

Volume 9 Nomor 2, Oktober 2021, P-ISSN 2302-6405, E-ISSN 2714-9765 
dilakukan, aku datang lagi dan ada lagi dihadapanmu". (Adegan 11, Hlm. 13)

Berdasarkan kutipan dialog di atas dapat disimpulkan bahwa nilai sosial yang dilakukan oleh tokoh Suherman. Hal itu dibuktikan oleh tokoh Suherman dalam adegan 11, di mana tokoh Suherman lebih mengutamakan kepentingan kelompok dibandingkan dengan kepentingan pribadinya.

\section{Relevansi Hasil Temuan dalam Naskah Drama Bunga Rumah Makan Karya Utuy Tatang Sontani Sebagai Bahan Ajar di Sekolah Menengah Atas (SMA) Kelas XI}

Proses pembelajaran di kelas tidak dapat terlaksana tanpa adanya persiapan yang dilakukan oleh seorang guru. Guru dalam memilih bahan ajar tidak boleh sembarangan karena dalam mempersiapkan bahan ajar harus sesuai dengan kurikulum. Kurikulum yang diterapkan di sekolah saat ini yaitu kurikulum 2013. Kurikulum 2013 merupakan kurikulum pengganti KTSP, di mana kurikulum 2013 lebih berstruktur dan lebih menekankan pendidikan karakter bagi siswa. Pendidikan karakter tidak hanya bersumber dari pembelajaran di ruang kelas akan tetapi pembelajaran karakter juga dapat diambil dari lingkungan sekitar yang menjadikan perilaku seseorang menjadi baik. Kompetensi pengetahuan dan kompetensi keterampilan merupakan komponen yang terdapat dalam kurikulum 2013 yang diterapkan dalam pembelajaran sastra di SMA. Pembelajaran sastra di SMA tercantum dalam kompetensi dasar yang telah ditentukan oleh Kementerian Pendidikan. Pembelajaran sastra tentang menelaah unsur-unsur naskah drama dapat dilihat dalam tabel kompetensi dasar berikut.

Tabel 1. Kompetensi Dasar Mata Pelajaran Bahasa Indonesia Kelas XI SMA

\begin{tabular}{|c|c|}
\hline Kompetensi Dasar & Indikator \\
\hline $\begin{array}{l}\text { 3.18 Mengidentifikasi } \\
\text { alur cerita, babak demi } \\
\text { babak, dan konflik dalam } \\
\text { drama yang dibaca atau } \\
\text { ditonton. }\end{array}$ & $\begin{array}{l}3.18 .1 \text { Mendata alur, } \\
\text { konflik, penokohan, dan } \\
\text { hal yan menarik dalam } \\
\text { drama yang } \\
\text { dipentaskan. }\end{array}$ \\
\hline $\begin{array}{l}\text { 4.18 Mempertunjukkan } \\
\text { salah satu tokoh dalam } \\
\text { drama yang dibaca atau } \\
\text { ditonton secara lisan. }\end{array}$ & $\begin{array}{l}\text { 4.18.1 Memerankan } \\
\text { salah satu tokoh dalam } \\
\text { naskah drama yang } \\
\text { dibaca sesuai dengan } \\
\text { tabiat tokoh tersebut. }\end{array}$ \\
\hline & $\begin{array}{l}\text { 4.18.2 Memberi } \\
\text { tanggapan, serta } \\
\text { memperbaiki hasil kerja } \\
\text { dalam diskusi kelas. }\end{array}$ \\
\hline $\begin{array}{l}\text { 3.19 Menganalisis isi dan } \\
\text { kebahasaan drama yang } \\
\text { dibaca atau ditonton. }\end{array}$ & $\begin{array}{l}\text { 3.19.1 Mengidentifikasi } \\
\text { isi dan kebahasaan } \\
\text { drama yang dibaca atau } \\
\text { ditonton. }\end{array}$ \\
\hline $\begin{array}{l}\text { 4.19 Mendemonstrasikan } \\
\text { sebuah naskah drama } \\
\text { dengan memperhatikan isi } \\
\text { dan kebahasaan. }\end{array}$ & 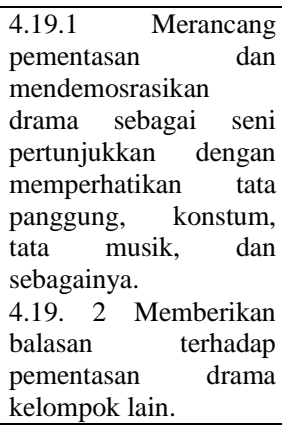 \\
\hline
\end{tabular}
dijadikan bahan ajar adalah naskah drama yang memiliki isi, bahasa yang baik dan tidak mengandung unsur SARA dan memilki nilai amanat yang dapat dipetik untuk diterapkan dalam kehidupan sehari-hari. Hal tersebut sejalan dengan hasil wawancara dengan guru bahasa Indonesia SMA Negeri 2 Surakarta yang memaparkan bahwa "Pembelajaran sastra, 
khususnya drama bagi sebagaian besar siswa adalah pembelajaran yang sangat ditunggu-tunggu. Beberapa kriteria pemilihan naskah drama yang dapat digunakan sebagai bahan ajar antara lain: (a) Isi cerita sesuai dengan perkembangan psikologis/usia, unik, menarik, dan penuh kejutan. Pemilihan cerita yang unik dan penuh kejutan akan menjadi daya tarik para siswa; (b) Bahasanya tidak terlalu rumit untuk dipahami, tidak banyak menggunakan istilah/kata-kata asing. Jika ceritanya terlalu berat ditambah dengan bahasa yang terlalu tinggi, banyak istilah khusus atau asing, sudah pasti tidak akan dilirik; (c) Memiliki nilai amanat yang dapat dipetik sehingga berbagai peristiwa yang terdapat dalam naskah drama akan menjadi pengalaman berharga dan menjadi gambaran kehidupan yang nyata bagi kehidupan yang nyata bagi para siswa untuk dapat menjadi bekal dalam menapaki kehidupan."

Naskah drama Bunga Rumah Makan karya Utuy Tatang Sontani layak dijadikan bahan ajar. Hal ini sejalan dengan hasil wawancara dengan guru bahasa Indonesia SMA Negeri 2 Surakarta yang menyatakan bahwa naskah drama Bunga Rumah Makan karya Utuy Tatang Sontani sangat layak untuk menjadi bahan ajar dalam pembelajaran sastra, khususnya di kelas XI dan sangat cocok diberikan ke siswa. Hal tersebut karena sesuai dengan perkembangan siswa yang sedang mencari jati diri sehingga dengan karakter tokoh Ani dan tokoh- tokoh lainya dapat menjadi contoh dalam bersikap dan berprilaku secara bijak.

Kelayakan naskah drama Bunga Rumah Makan karya Utuy Tatang Sontani sebagai bahan ajar juga dinilai menggunakan instrumen penilaian B3 pengayaan kepribadian di mana peniliaian ini dikembangkan oleh pusat kurikulum dan perbukuan. Penilaian B3 digunakan untuk menilai buku nonfiksi dan buku fiksi. Instrumen penilian B3 mencakup penilaian isi/materi dengan skor keseluruhan mencapai 144, penyajian dengan skor keseluruhan mencapai 118, bahasa dengan skor keseluruhan mencapai 45, dan grafik mencapai skor secara keseluruhahan mencapai 23, di mana hasil penilaian dari naskah drama Bunga Rumah Makan dinyatakan layak karena skor dari materi/isi, penyajian, bahasa grafika melampui skor 330 . Kemudian skor tersebut dihitung nilai korelasinya dan nilai korelasi dari nilai tersebut adalah 1 yang memiliki arti sangat kuat, sangat kuat berarti mempunyai arti sangat layak. Instrumen penilian B3 menjadi indikator kelayakan yang menjadikan naskah drama Bunga Rumah Makan karya Utuy Tatang Sontani layak dijadikan sebagai bahan ajar di SMA.

Berdasarkan hasil wawancara dan hasil penilaian menggunakan instrumen penilaian B3 dapat dinyatakan bahwa naskah drama Bunga Rumah Makan layak dijadikan sebagai bahan ajar sastra di SMA. Hasil penelitian tersebut sejalan dengan 
kompetensi dasar yang tercantum di atas. Naskah drama ini termasuk naskah drama yang memenuhi kriteria sebagai bahan ajar pembelajaran sastra di SMA.

\section{SIMPULAN}

Berdasarkan hasil penelitian yang telah dilakukan mengenai struktur, konflik batin tokoh utama, nilai pendidikan, dan relevansi naskah drama Bunga Rumah Makan karya Utuy Tatang Sontani sebagai bahan ajar sastra di SMA terdapat beberapa kesimpulan. Naskah drama Bunga Rumah Makan karya Utuy Tatang Sontani memiliki struktur yang saling berkaitan satu sama lain. Struktur tersebut meliputi tema, alur, tokoh, latar, dan amanat.

Konflik batin tokoh utama naskah drama Bunga Rumah Makan karya Utuy Tatang Sontani, yaitu mengenai kebutuhan fisiologis, kebutuhan rasa aman, kebutuhan rasa cinta dan memiliki, kebutuhan harga diri, dan kebutuhan aktualisasi diri. Ani sebagai tokoh utama belum memenuhi kebutuhan meskipun Ani sudah berusaha untuk memenuhi kebutuhanya. Ani sebagai tokoh utama dalam naskah drama Bunga Rumah Makan karya Utuy Tatang Sontani memandang bahwa dirinya belum dapat memenuhi kebutuhannya. Psikologi memandang ketika orang tersebut dapat memenuhi kebutuhanya maka akan terlihat pada diri orang tersebut karena ilmu psikologi dilihat dari dalam diri seseorang itu sendiri.
Naskah drama Bunga Rumah Makan karya Utuy Tatang Sontani terdapat nilai-nilai pendidikan. Nilainilai pendidikan mampu menjadi sarana edukasi bagi siswa Sekolah Menengah Atas. Nilai pendidikan tersebut, yaitu nilai religius, nilai moral, dan nilai pendidikan sosial.

Naskah drama Bunga Rumah Makan karya Utuy Tatang Sontani relevan digunakan sebagai bahan ajar pembelajaran sastra di SMA. Aspek isi sudah sesuai dengan kelayakan standar yang disesuaikan karena isi naskah drama sesuai dengan perkembangan siswa, aspek bahasa sudah sesuai karena bahasanya tidak terlalu rumit dan mudah dipahami, penyajian dan grafis naskah sudah sesuai karena sudah sesuai dengan kelayakan ketentuan peniliaian. Naskah drama Bunga Rumah Makan karya Utuy Tatang Sontani memenuhi kriteria sebagai salah satu drama yang dapat menjadi bahan ajar pembelajaran sastra kelas XI SMA.

Hasil penelitian tentang struktur naskah drama Bunga Rumah Makan karya Utuy Tatang Sontani dapat dijadikan sebagai referensi bahan ajar oleh guru bahasa Indonesia khususnya kelas XI Sekolah Menengah Atas. Pembelajaran kelas XI terdapat kompetensi dasar 3.18 dan 4.18 serta 3.19 dan 4.19 yang membahas tentang naskah drama. Guru dapat menjadikan hasil penelitian struktur drama dan mengambil kutipan-kutipan yang terkandung dalam hasil penelitian naskah drama Bunga Rumah Makan 
karya Utuy Tatang Sontani sebagai bahan ajar sehingga siswa mampu memahami penjelasan dari guru dengan baik.

\section{REFERENSI}

Djojosuroto, K. (2006). Teks Sastra dan Pengajaranya. Yogyakarta: Pustaka.

Minderop, A. (2011). Metode Karakteristik Telaah Fiksi. Jakarta: Yayasan Pustaka Obor Indonesia.

Minderop, A. (2011). Psikologi Sastra: Karya Sastra, Metode, Teori dan Contoh Kasus. Jakarta:

Yayasan Pustaka Obor Indonesia.

Meoleong, L. (2012). Metodelogi Penelitian Kualitatif. Bandung: PT Remaja Rosda Jaya.

Nuriadi., Baharudin., Isnaini, M., \& Fadjri, M. (2021). Peningkatan Kemampuan Apresiasi sastra Untuk Siswa SMA Negeri 1 Praya Lombok Tengah. Jurnal Pengabdian Magister Pendidikan IPA. 4(1), 162-168.

Nurgiyantoro, B. (2012). Teori Pengakajian dan Fiksi. Yogyakarta: Gadjah Mada University Press.

Suhariadi. (2016). Pembelajaran Sastra: Prinsip, Konsep, dan Model Pembelajaran Sastra. Jurnal Teladan. 1(1), 59-72.

Sujanto, A., Lubis, H., \& Hadi, T. (2004). Psikologi Kepribadian. Jakarta: PT. Bumi Aksara.

Yanti, P.G. \& Hidayatullah, S. (2018). Representasi Ekranisasi Novel Dear Nathan Karya Erisca. Imajeri: Jurnal Pendidikan
Bahasa dan Sastra Indonesia. 1(1), 45-50.

Waluyo, H J. (2001). Drama: Teori dan Pengajaranya. Yogyakarta: Hanindita Graha Widia.

(2002). Pengkajian Prosa Fiksi. Surakarta: UNS Press.

Wiyatmi. (2011). Psikologi Sastra. Yogyakarta: Kanwa Publisher.

Zaghloul, H. S. (2018). Using Creative Educational Drama to EnhanceSelf Development Skills for the Students at University Level. International Journal of Advanced Computer Science and Applications, 9(4), 71-77.

BASASTRA Jurnal Bahasa, Sastra, dan Pengajarannya

Volume 9 Nomor 2, Oktober 2021, P-ISSN 2302-6405, E-ISSN 2714-9765 